\title{
DAMPAK OTONOMI KEUANGAN DAERAH TERHADAP PERTUMBUHAN EKONOMI DI INDONESIA
}

\author{
Nurhemi ${ }^{1}$ \\ Guruh Suryani $R^{2}$
}

\begin{abstract}
Paper ini menganalisis dampak otonomi keuangan daerah terhadap pertumbuhan ekonomi regional di Indonesia. Metode estimasi panel diaplikasikan pada data 26 propinsi selang kurun 1990-2011, yang dibagi kedalam tiga interval yakni jangka panjang 1990-2011, sebelum desentralisasi 1990-2000 dan sesudah desentralisasi 2001-2011. Hasil estimasi pada data nasional menunjukkan bahwa otonomi keuangan (diwakili dengan Derajat Desentralisasi Fiskal) berpengaruh positif terhadap pertumbuhan ekonomi. Namun demikian, pada sub sampel masing-masing wilayah, pengaruh positif dari pendapatan per kapita terhadap pertumbuhan hanya terbukti pada wilayah Jawa dan Bali dan hanya berlaku dalam periode observasi panjang (1990-2011). Temuan ini menggiring pada kesimpulan bahwa pengaruh desentralisasi fiskal terhadap pertumbuhan ekonomi, tidak konskusif untuk kasus desentralisasi di Indonesia.
\end{abstract}

Keywords: Unemployment, income distribution, inflation, fiscal policy, investment

JEL Classification: E22, E24, E31, E62

1. Senior researcher on Central Banking Research Department, Bank Indonesia. (emmy@bi.go.id)

2. Researcher on Bank Indonesia Institute, Bank Indonesia (guruh_sr@bi.go.id).

The views on this paper is solely of the authors and not necessarily reflect the views of Bank Indonesia 


\section{PENDAHULUAN}

Pelaksanaan Otonomi Daerah telah dilakukan banyak negara termasuk Indonesia. Otonomi atau desentralisasi dimaksudkan untuk memberikan pelayanan publik yang lebih baik dan menciptakan proses pengambilan keputusan publik yang lebih demokratis. Wujud desentralisasi ini berupa pemberian wewenang dari pemerintah pusat kepada tingkat pemerintahan dibawahnya untuk melakukan pembelanjaan, memungut pajak, terbentuknya dewan yang dipilih rakyat, memilih kepala daerah oleh rakyat dan adanya bantuan (transfer) dari pemerintah pusat. Umumnya desentralisasi mencakup aspek politik, administratif dan fiskal (Abimanyu dan Megantara, 2009).

Di Indonesia, upaya serius untuk melaksanakan desentralisasi dimulai setelah masa krisis tahun 1997/1998. Secara formal desentralisasi mulai berlaku sejak 1 Januari 2001, pada masa ini dasar hukum pemberlakuan desentralisasi dibuat undang-undang baru yang menggantikan Undang-Undang No. 5 Tahun 1974 yakni Undang-Undang No.22 tahun 1999 tentang Pemerintahan Daerah dan Undang-Undang No. 25 tahun 1999 tentang Perimbangan Keuangan antara Pemerintah Pusat dan Daerah. Kemudian Undang-Undang ini diperbaharui dengan Undang-undang No.32 tahun 2004 tentang Pemerintahan Daerah dan Undang-Undang No.33 Tahun 2004 tentang Perimbangan Keuangan Pusat dan Daerah yang memberikan kewenangan atau otonomi yang luas, nyata dan bertanggung jawab kepada pemerintah daerah secara proporsional.

Selama sepuluh tahun pelaksanaan desentralisasi fiskal sejak tahun 2001 hingga 2011, penerimaan daerah-daerah di Indonesia tumbuh sebesar 321,4\%. Peningkatan penerimaan yang signifikan besar disebabkan meningkatnya sumber penerimaan daerah dari dana bagi

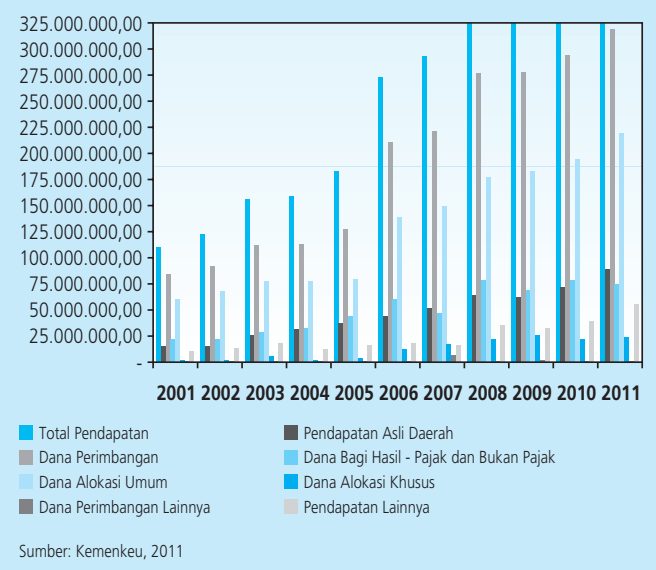

Grafik 1.

Komposisi Penerimaan Daerah di Indonesia (Juta Rupiah) 
hasil pajak dan bukan pajak (BHPBP), serta dana alokasi umum (DAU). Apabila kita tinjau berdasarkan komponen atau sumber penerimaan daerah, maka komponen terbesar dari penerimaan daerah adalah dana perimbangan berupa DAU, BHPBP, dan Dana Alokasi Khusus (DAK) yang memiliki kontribusi rata-rata sebesar 73\% dari total penerimaan daerah. Sedangkan Pendapatan Asli daerah (PAD) hanya memberikan kontribusi rata-rata sekitar 17\%. Rendahnya proporsi penerimaan PAD dibandingkan dengan dana perimbangan mengindikasikan belum optimalnya pemerintah daerah dalam menggali sumber-sumber penerimaan. Dapat dikatakan bahwa secara umum penerimaan pemerintah daerah masih didominasi oleh transfer dari Pemerintah Pusat berupa DAU dan BHPBP.

Dari sisi pengeluaran, total belanja daerah dari tahun 2001 hingga tahun 2011 mengalami pertumbuhan yang cukup signifikan. Secara total belanja daerah mengalami pertumbuhan sebesar $430 \%$ dalam kurun waktu tersebut. Sementara itu belanja rutin tumbuh 313,8\%, sedangkan belanja modal/pembangunan tumbuh sebesar $263 \%$ pada periode yang sama. Dari komposisi belanja daerah secara proporsional ternyata pengeluaran pemerintah daerah sebagian besar digunakan untuk pengeluaran rutin yang mencapai rata-rata 59\%, bahkan proporsinya terus bertambah seiring berjalannya waktu. Sementara itu, untuk pengeluaran pembangunan share-nya rata mencapai $41 \%$.

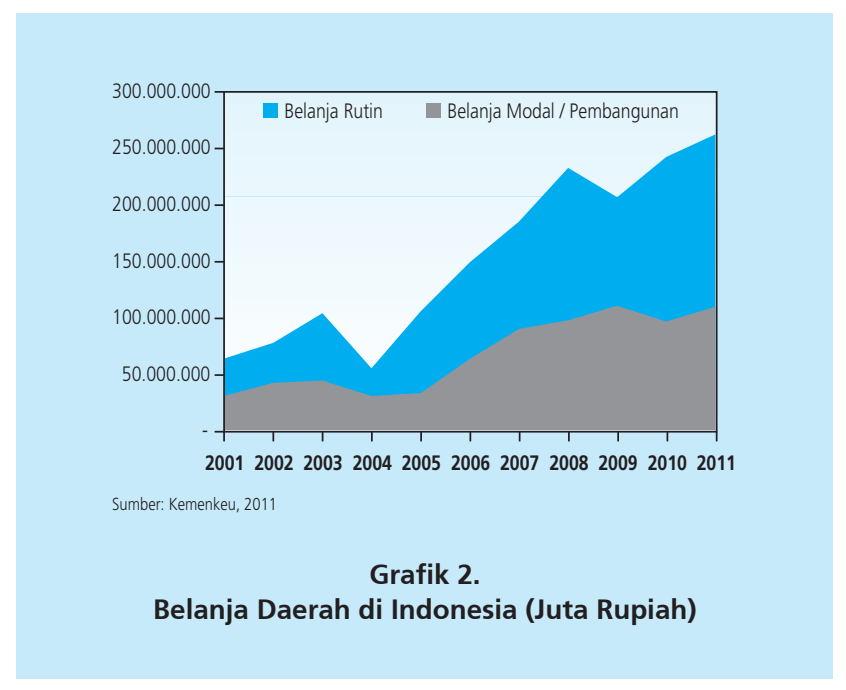

Tujuan desentralisasi fiskal bertujuan untuk memenuhi aspirasi daerah menyangkut penguasaan atas sumber-sumber keuangan negara, mendorong akuntabilitas dan transparansi pemerintah daerah, meningkatkan pastisipasi masyarakat dalam proses pembangunan daerah, mengurangi ketimpangan antar daerah, menjamin terselenggaranya pelayanan publik minimum di setiap daerah, dan pada akhirnya diharapkan dapat meningkatkan kesejahterahaan masyarakat secara umum, (Simanjuntak, 2002). Argumen ini tidak terlepas dari keyaninan 
bahwa pembangunan tidak dapat tercapai dengan hanya melalui mekanisme pasar, malainkan memerlukan peran pemerintah melalui kebijakan anggarannya.

Desentralisasi fiskal dapat menjadi alat efektif untuk meningkatkan efisiensi pengeluaran publik. Hipotesis ini memberikan indikasi bahwa terdapat potensi untuk mencapai efisensi ekonomi dalam penyediaan barang pada tingkat lokal. Terdapat beberapa penelitian empiris yang mendukung argumen perlunya desentralisasi fiskal; antara lain untuk mencapai efisiensi dalam alokasi sumber daya publik (Oates, 1972). Desentralisasi fiskal akan meningkatkan pendapatan dan meningkatkan efisiensi dalam sektor publik, dan memotong defisit anggaran serta meningkatkan pertumbuhan ekonomi (Bird, 1993; Bahl, Linn, 1992; Gramlich, 1993; dan Oates, 1993).

Zang dan Zou (1998) mengemukakan bahwa desentralisasi pengeluaran dan penerimaan merupakan bagian untuk memperbaiki efisiensi dari sektor publik, memotong anggaran defisit dan mendorong pertumbuhan ekonomi. Hal ini dikarenakan desentralisasi akan meningkatkan efisensi ekonomi karena pemerintah daerah akan memberikan jasa publik sesuai sesuai kebutuhan masyarakat. Dalam perjalanan waktu efisensi ini akan menyebabkan pertumbuhan ekonomi daerah bertambah cepat. Brothaler \& Getzner (2010) dan Faridi (2011) menemukan hal yang sama dengan Zang dan Zou bahwa desentralisasi fiskal secara signifikan mendorong pertumbuhan ekonomi daerah jangka pendek dan jangka panjang.

Menjadi menarik kemudian untuk mempertanyakan apakah fakta-fakta di atas juga berlaku untuk Indonesia; yakni apakah desentralisasi fiskal di daerah mampu memberikan pengaruh positif terhadap pertumbuhan ekonomi di Indonesia. Paper ini meneliti 26 propinsi di Indonesia dalam kurun waktu 1990-2011.

Bagian selanjutnya dari paper ini menguraikan acuan teori dan literatur yang terkait dengan permasalahan yang diangkat. Bagian ketiga menyajikan data dan metode pengolahannya. Bagian keempat menyajikan hasil dan análisis, sementara bagian kelima menyajikan kesimpulan dan saran.

\section{TEORI}

Kebijakan fiskal secara umum mengatur tentang penerimaan dan pengeluaran negara yang terdiri dari tiga kegiatan pokok; pertama, kebijakan yang terkait pembelian pemerintah atas barang dan jasa; kedua, kebijakan terkait perpajakan; dan ketiga, kebijakan terkait pembayaran transfer (misal tunjangan keamanan sosial, pembayaran kesejahterahaan) kepada rumah tangga.

Sumber-sumber penerimaan negara antara lain berasal dari pajak, penerimaan bukan pajak dan pinjaman luar negeri. Sementara itu pengeluaran diperuntukan kedalam pengeluaran yang bersifat rutin dan untuk pembangunan. Perkembangan pengeluaran pemerintah dalam perkembangannya digolongkan menjadi tiga bagian (Mangkoesoebroto 1997) yakni: 
1. Model pembangunan terkait pengeluaran pemerintah yang dikembangkan Rostow dan Musgrave (1991) yang mengemukakan bahwa dalam proses pembangunan, makin besar persentase investasi swasta terhadap PDB, maka persentase investasi pemerintah terhadap PDB akan semakin kecil.

2. Hukum Wagner yang menyatakan bahwa apabila pendapatan perkapita meningkat maka secara relatif pengeluaran pemerintah akan meningkat.

3. Teori Peacock dan Wisemen menyatakan pertumbuhan ekonomi (PDB) menyebabkan pemungutan pajak meningkat meski tarif pajak tidak dinaikan.

Desentralisasi merupakan alat untuk meningkatkan layanan publik dan kesejahteraan masyarakat. Implementasi desentralisasi terutama terdiri dari pembagian fungsi/tugas/ kewenangan antar level pemerintahan. Desentralisasi fiskal biasanya didahului reformasi dari sisi pengeluaran, kemudian diikuti oleh sisi penerimaan.

Sejarah otonomi daerah di Indonesia sudah dimulai pada zaman kemerdekaan. Sejarah ini sempat terhenti saat diterapkannya sentralisasi pemerintahan pada era orde baru. Kemudian, perjalanan desentralisasi dilanjutkan seiring dengan berkembangnya era reformasi di Indonesia. Namun, ketidaksiapan institusi dan masyarakat dalam menghadapi desentralisasi ini mengakibatkan ketidakseimbangan vertikal dan horizontal.

Untuk mengukur dan membandingkan tingkat desentralisasi fiskal antar negara dapat dilakukan dengan melihat besarnya kewenangan atas penerimaan yang dipegang oleh daerah, dibandingkan dengan besarnya kewenangan belanja daerah.

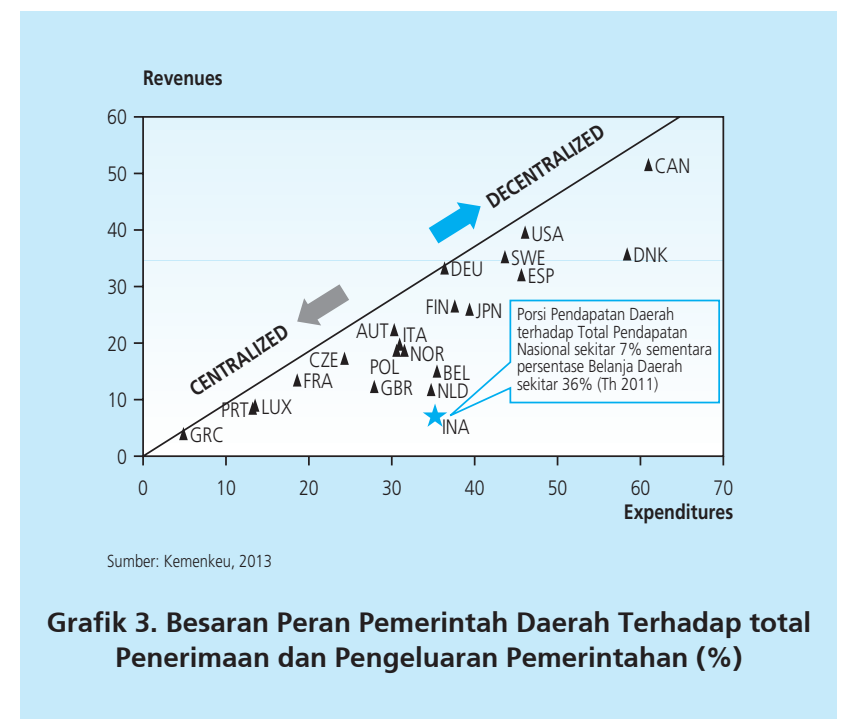


Dari gambar di atas dapat dilihat bahwa desentralisasi fiskal di Indonesia lebih menekankan kepada desentralisasi dari sisi pengeluaran. Dengan demikian implementasi desentralisasi fiskal lebih mengutamakan pemberian sumber pendanaan melalui transfer ke daerah, yang diiringi kewenangan yang luas untuk membelanjakannya.

Untuk mendukung dan mempercepat pencapaian tujuan nasional, maka kebijakan makro ekonomi harus dilakukan melalui harmonisasi arah kebijakan fiskal, moneter, sektor riil maupun neraca pembayaran. Untuk mewujudkan kebijakan makro yang sehat perlu didukung oleh kebijakan keuangan daerah yang sejalan dengan kebijakan fiskal nasional.

Selain dana transfer ke daerah, pemerintah pusat juga mengalokasikan sebagian besar belanja untuk mendanai urusan pusat di daerah dan pelayanan kepada masyarakat, antara lain melalui subsidi, dana dekonsentrasi dan tugas pembantuan, bantuan masyarakat melalui PNPM dan Jamkesmas, hibah, dll. Apabila dihitung secara keseluruhan, maka dana yang mengalir ke daerah telah mencapai kisaran 60\% dari belanja negara. Gambar di bawah ini memperlihatkan alur belanja Pemerintah Pusat ke daearh.

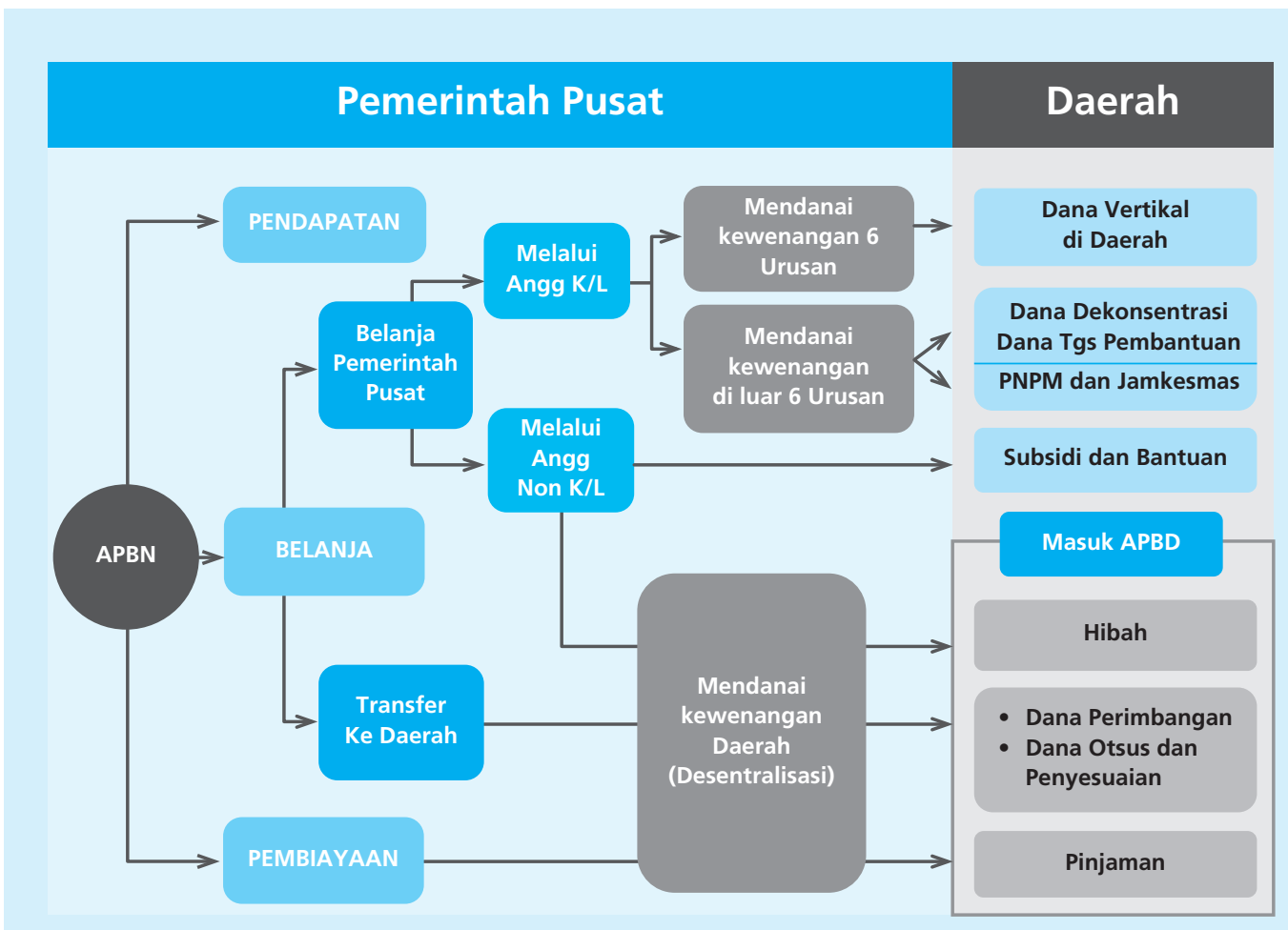

Sumber: Kemenkeu, 2013

Gambar 1.

Alur Belanja APBN ke Daerah 
Kebijakan desentralisasi fiskal pada dasarnya mengikuti prinsip money follows function, dimana penyerahan beban kewenangan kepada daerah harus diikuti dengan penyerahan sumber-sumber pendanaan kepada daerah. Penyerahan sumber pendanaan terutama dilakukan melalui penyerahan kewenangan untuk memungut pajak daerah dan retribusi daerah, dan penyerahan pendanaan melalui transfer ke daerah.

Desentralisasi fiskal di Indonesia menitikberatkan pada desentralisasi di sisi pengeluaran, sehingga pemberian kewenangan pungutan perpajakan daerah dan retribusi daerah relatif terbatas, namun kepada daerah diberikan kewenangan yang luas untuk melakukan pengeluaran sesuai prioritas dan kebutuhan daerah. Sebagian besar dana transfer ke daerah bersifat block grant (dapat digunakan secara bebas oleh daerah dan dipertanggungjawabkan sepenuhnya di level daerah, yaitu kepada DPRD).

Untuk mendukung pencapaian prioritas nasional, kepada daerah juga diberikan transfer yang bersifat specific grant (diarahkan penggunaannya oleh Pemerintah Pusat), antara lain melalui Dana Alokasi Khusus (DAK) sehingga dapat menjaga keterkaitan antara program di Pusat dan daerah. Untuk menjaga governance penggunaan dana publik, maka pengelolaan APBD harus mengacu kepada pola pengelolaan keuangan Negara yang diatur dalam paket UU Keuangan Negara.

Kebijakan transfer ke daerah dimaksudkan antara lain untuk:

- Meningkatkan kapasitas fiskal daerah dan mengurangi kesenjangan fiskal antara pusat \& daerah dan antar daerah.

- Menyelaraskan kebutuhan pendanaan di daerah sesuai dengan pembagian urusan pemerintahan.

- Meningkatkan kualitas pelayanan publik di daerah \& mengurangi kesenjangan pelayanan publik antar daerah.

- Meningkatkan kemampuan daerah dalam mendorong perekonomian daerah.

- Mendukung kesinambungan fiskal nasional.

- Meningkatkan efisiensi pemanfaatan sumber daya nasional.

- Meningkatkan sinkronisasi antara rencana pembangunan nasional dengan rencana pembangunan daerah. 


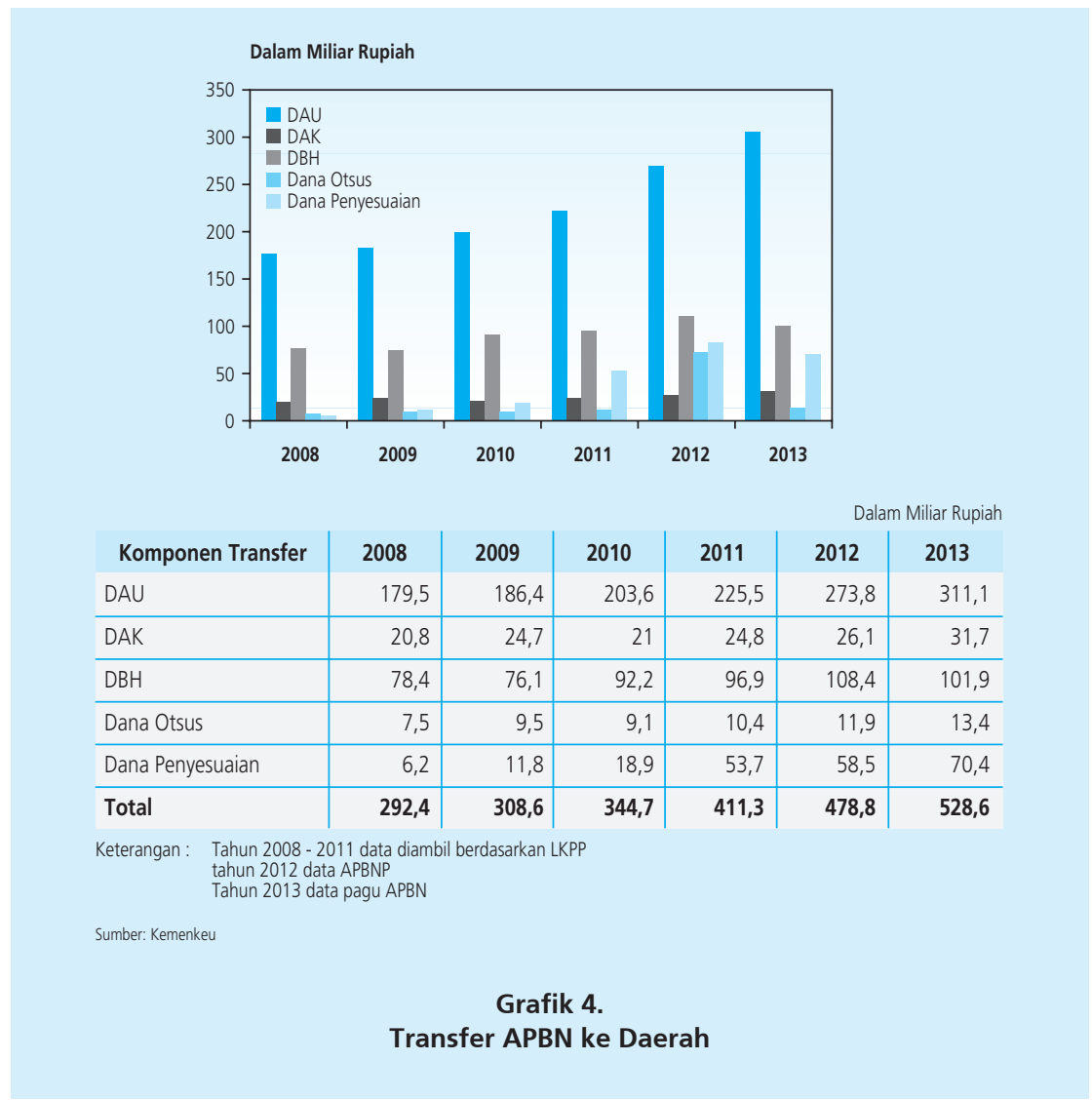

Sementara itu struktur belanja APBD cenderung tidak proporsif antara pengeluaran rutin, belanja modal dan lainnya.

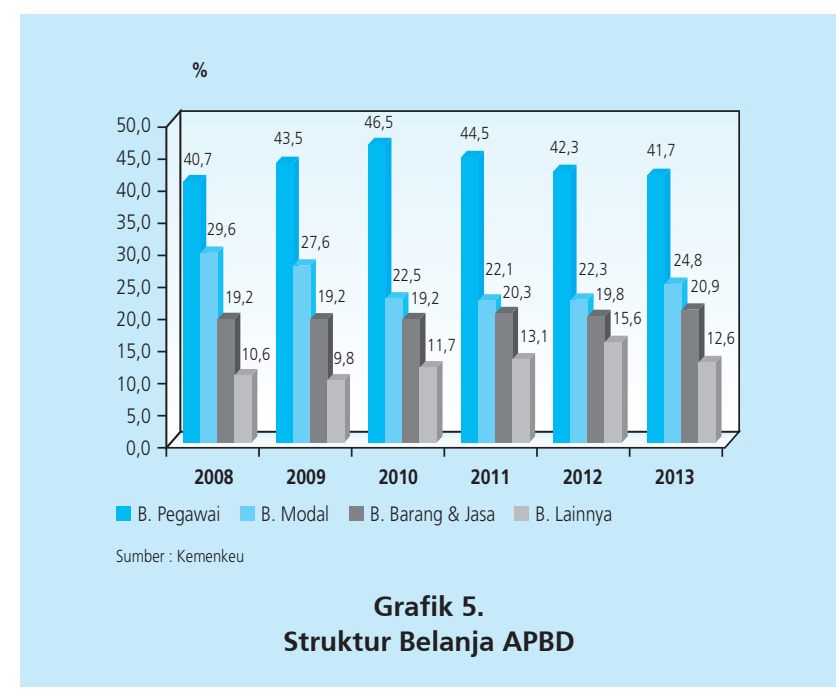




\begin{tabular}{|c|c|c|c|c|}
\hline \multicolumn{5}{|c|}{$\begin{array}{c}\text { Tabel } 1 . \\
\text { Hubungan Desentralisasi Fiskal dan Beberapa Indikator Ekonomi Makro di Beberapa Negara }\end{array}$} \\
\hline $\begin{array}{l}\text { Indikator } \\
\text { Makro }\end{array}$ & Peneliti(Tahun) & Sampel & $\begin{array}{l}\text { Metodologi } \\
\text { Penelitian }\end{array}$ & Hasil Penelitian \\
\hline \multirow[t]{6}{*}{$\begin{array}{l}\text { Pertumbuhan } \\
\text { ekonomi daerah }\end{array}$} & $\begin{array}{l}\text { Akai \& Sakata } \\
(2002)\end{array}$ & $\begin{array}{l}50 \text { negara bagian di } \\
\text { Amerika Serikat } \\
1992-1996\end{array}$ & Regresi OLS & $\begin{array}{l}\text { Desentralisasi fiskal secara signifikan } \\
\text { mendorong pertumbuhan ekonomi daerah }\end{array}$ \\
\hline & $\begin{array}{l}\text { Brothaler \& } \\
\text { Getzner. (2010) }\end{array}$ & $\begin{array}{l}\text { Propinsi di Austria } \\
1955-2007\end{array}$ & $\begin{array}{l}\text { GARCH dan uji } \\
\text { kointegrasi }\end{array}$ & $\begin{array}{l}\text { Desentralisasi fiskal secara signifikan } \\
\text { mendorong pertumbuhan ekonomi daerah } \\
\text { jangka pendek dan jangka panjang }\end{array}$ \\
\hline & $\begin{array}{l}\text { Bahl \& Wallace. } \\
(2006)\end{array}$ & $\begin{array}{l}21 \text { Region di Rusia } \\
\text { tahun } 1997\end{array}$ & Regresi OLS & $\begin{array}{l}\text { Desentralisasi fiskal secara signfikan } \\
\text { memiliki hubungan positif dengan tingkat } \\
\text { pertumbuhan ekonomi daerah }\end{array}$ \\
\hline & $\begin{array}{l}\text { Pose \& Krojer. } \\
(2009)\end{array}$ & $\begin{array}{l}\text { Negara-negara CEE } \\
\text { tahun 1990-2004 }\end{array}$ & Regresi OLS & $\begin{array}{l}\text { Desentralisasi fiskal secara signifikan } \\
\text { menghambat pertumbuhan ekonomi daerah }\end{array}$ \\
\hline & $\begin{array}{l}\text { Zhang \& Zou } \\
(1998)\end{array}$ & $\begin{array}{l}\text { Propinsi di China } \\
\text { 1978-1992 }\end{array}$ & $\begin{array}{l}\text { Regresi Least } \\
\text { Square Dummy } \\
\text { variables }\end{array}$ & $\begin{array}{l}\text { Desentralisasi fiskal secara signifikan } \\
\text { menghambat pertumbuhan ekonomi daerah }\end{array}$ \\
\hline & Faridi (2011) & $\begin{array}{l}\text { Propinsi di Pakistan } \\
\text { tahun 1972-2009 }\end{array}$ & Regresi OLS & $\begin{array}{l}\text { Desentralisasi fiskal mengurangi } \\
\text { ketergantungan propinsi terhadap pusat } \\
\text { dan meningkatkan pertumbuhan ekonomi } \\
\text { di daerahnya }\end{array}$ \\
\hline Kemiskinan & $\begin{array}{l}\text { Sepulveda, C.F \& } \\
\text { Vazquez, J. M. } \\
\text { (2011) }\end{array}$ & $\begin{array}{l}34 \text { negara sedang } \\
\text { berkembang di Afrika } \\
1976-2000\end{array}$ & GSLS & $\begin{array}{l}\text { Desentralisasi fiskal secara signifikan } \\
\text { memiliki hubungan negatif dengan } \\
\text { kemiskinan. }\end{array}$ \\
\hline \multirow[t]{3}{*}{$\begin{array}{l}\text { Ketimpangan } \\
\text { wilayah }\end{array}$} & $\begin{array}{l}\text { Nugrahanto \& } \\
\text { Muhyiddin (2008) }\end{array}$ & $\begin{array}{l}\text { Propinsi Indonesia } \\
2001-2004\end{array}$ & $\begin{array}{l}\text { Fixed effect } \\
\text { regression }\end{array}$ & $\begin{array}{l}\text { Desentralisasi fiskal di Indonesia secara } \\
\text { signifikan meningkatkan kesenjangan antar } \\
\text { daerah di Idnonesia. }\end{array}$ \\
\hline & Lessmann (2006) & $\begin{array}{l}\text { Negara-negara } \\
\text { OECD tahun 1980- } \\
2001\end{array}$ & Regresi OLS & $\begin{array}{l}\text { Desentralisasi fiskal yang tinggi terkait } \\
\text { dengan ketimpangan wilayah yang rendah }\end{array}$ \\
\hline & $\begin{array}{l}\text { Sepulveda, C.F \& } \\
\text { Vazquez, J. M. } \\
(2011)\end{array}$ & $\begin{array}{l}34 \text { negara sedang } \\
\text { berkembang di Afrika } \\
1976-2000\end{array}$ & GSLS & $\begin{array}{l}\text { Desentralisasi fiskal secara signifikan } \\
\text { mengurangi ketimpangan wilayah }\end{array}$ \\
\hline \multirow[t]{3}{*}{ Pengangguran } & $\begin{array}{l}\text { Freinkman. } \\
\text { (2010) }\end{array}$ & $\begin{array}{l}73 \text { Region di Rusia } \\
\text { tahun 2004-2005 }\end{array}$ & Regresi OLS & $\begin{array}{l}\text { Pengeluaran pemerintah secara signifikan } \\
\text { mendorong kualitas pendidikan }\end{array}$ \\
\hline & $\begin{array}{l}\text { Faridi, Chaudry \& } \\
\text { Ansari(2012) }\end{array}$ & $\begin{array}{l}\text { Propinsi di Pakistan } \\
\text { tahun 1972-2009 }\end{array}$ & Regresi OLS & $\begin{array}{l}\text { Desentralisasi fiskal secara signifikan } \\
\text { mendorong kesempatan kerja }\end{array}$ \\
\hline & $\begin{array}{l}\text { Vazquez \& Yao } \\
(2009)\end{array}$ & $\begin{array}{l}\text { Negara-negara } \\
\text { OECD tahun 1985- } \\
2005\end{array}$ & 2SLS dan GMM & $\begin{array}{l}\text { Desentralisasi fiskal secara signifikan } \\
\text { mendorong kesempatan kerja }\end{array}$ \\
\hline
\end{tabular}


Proporsi terbesar belanja daerah adalah belanja pegawai meskipun terus menurun di 3 tahun terakhir. Proporsi belanja modal relatif kecil, meskipun mengalami peningkatan di tahun 3 tahun terakhir.

Tabel di atas menunjukkan beberapa literatur empiris tentang pengaruh desentralisasi fiskal. Oates (1972), Wasykuko (1987) berpendapat bahwa desentralisasi fiskal diukur dari share pengeluaran atau pendapatan pemerintah daerah terhadap anggaran pemerintah pusat. Hubungan ini biasanya berkorelasi secara positif dengan perkembangan ekonomi yakni diukur dengan pendapatan perkapita. Temuan yang serupa juga dikemukakan oleh Deparap, Swarop \& Zou (1996) menemukan hubungan yang positif antar share pengeluaran pemerintah pusat terhadap pertumbuhan. Easterly dan Robelo (1993) menemukan hubungan yang positif untuk belanja infrastruktur dengan pertumbuhan.

Sementara itu Baro (1990) menemukan hal yang berbeda yakni peningkatan share konsumsi pemerintah pusat terhadap GDP memiliki hubungan yang negatif dengan pertumbuhan dan pendapatan perkapita. Kesemuanya ini tidak menyentuh tingkat desentralisasi atau komposisi intergovernmental dari pengeluaran publik terhadap pertumbuhan ekonomi.

Zhang \& Zou (1998) mengkaji bagaimana alokasi sumber daya fiskal antara pemerintah pusat dan lokal dalam mempengaruhi pertumbuhan ekonomi. Sampel penelitian yang digunakan yaitu propinsi di China 1978-1992. Hasil penelitian menunjukkan bahwa tingkat desentralisasi fiskal pengeluaran pemerintah yang lebih tinggi menghambat pertumbuhan ekonomi propinsi. Hasil yang signifikan ini tidak sesuai dengan teori dan hasil penelitian lainnya, yang biasanya memperkuat argumen bahwa desentralisasi fiskal berkontribusi positif bagi pertumbuhan ekonomi lokal.

Davoodi dan Zou (1997) yang meneliti desentralisasi fiskal dengan pertumbuhan ekonomi: cross country study dan menemukan untuk negara-negara berkembang terdapat hubungan yang negatif dan juga untuk dunia, sementara untuk negara maju tidak ada hubungan untuk negara-negara maju.

Studi yang dilakukan oleh Braun dan Grote (2000) mengenai desentralisasi dan kemiskinan menemukan pembiayaan publik merupakan elemen utama dari kebijakan pengurangan kemiskinan. Akan tetapi negara-negara dengan pendapatan rendah memliki masalah rendahnya penerimaan publik yang rata-rata mencapai $17,5 \%$. Sementara itu untuk negara-negara berpendapatan tinggi revenue hampir mencapai 30\%. Di daerah terdapat permasalahan desain dan implementasi pengumpulan pajak yang tidak diorganisir dengan baik, kurang transparan. Biaya untuk mengumpulkan pendapatan dinegara-negara miskin sangat tinggi dan kadang melebihi keuntungan dari pengeluaran publik. Namun permasalahan nyatanya adalah terbatasnya sumber-sumber publik seperti pendidikan, kesehatan, yang dapat menolong penduduk miskin untuk mengakumulasi asset mereka.

Penelitian yang dilakukan oleh Nugrahanto \& Muhyiddin (2008) mengkaji secara empiris dampak desentralisasi fiskal dengan ketimpangan wilayah di Indonesia. Pandangan konvensional 
menyatakan bahwa desentralisasi fiskal meningkatkan ketimpangan wilayah karena tekanan dari pemerintah pusat untuk redistribusi pendapatan antara daerah menjadi lebih rendah setelah desentralisasi fiskal. Di sisi lain, desentralisasi fiskal mendorong upaya peningkatan pendapatan asli daerah untuk membiayai pengeluaran daerah, sehingga tidak tergantung pada hibah dari pemerintah pusat. Sampel penelitian yang digunakan yaitu data propinsi Indonesia 2001-2004. Hasil penelitian menunjukkan ketika desentralisasi fiskal meningkat, ketimpangan wilayah pun ikut meningkat. Namun, Nugrahanto \& Muhyiddin (2008) menyarankan untuk mengkaji ulang karena dari hasil penelitian ini masih belum memadai untuk menyimpulkan dampak desentralisasi fiskal terhadap ketimpangan wilayah. Hasil ini agak diragukan karena keterbatasan data (4 tahun). Namun dimungkinkan juga adanya korelasi baik ketimpangan regional dan desentralisasi atau variable independen lain.

Swastyardi (2008) dalam penelitiannya mengenai Regional Inequality in Indonesia menemukan bahwa ketimpangan secara nasional adalah pada level yang stabil tidak banyak berfluktuasi dan cenderung turun pada periode 2001-2006. Namun pada periode 2001-2003 ketimpangan pada level nasional cenderung turun kecuali Kalimantan dan Sulawesi. Kondisi ini mengindikasikan kebijakan implementasi pada pemerintahan daerah lebih efektif dibandingkan sebelum desentralisasi fiskal diterapkan. Efek dari desentralisasi fiskal adalah mengurangi level ketimpangan. Selain itu terdapat indikasi bahwa DAU mempunyai dampak terhadap ketimpangan. Terdapat tiga efek yaitu;

1. Peningkatan DAU yang diikuti penurunan ketimpangan. Kondisi ini terjadi pada level nasional, Sumatera, Jawa dan Bali.

2. Peningkatan DAU diikuti peningkatan ketimpangan, ini terjadi di Kalimantan dan Sulawesi.

3. Peningkatan DAU diikuti patern yang fluktuatif pada ketimpangan.

Banyak negara di dunia menerapkan kebijakan dalam rangka mengurangi tingkat kemiskinan dan memperbaiki distribusi pendapatan antara lain melalui kebijakan desentralisasi fiskal. Sepulveda, C.F \& Vazquez, J. M. (2011) melakukan penelitian yang berfokus pada dampak desentralisasi fiskal terhadap kemiskinan dan ketimpangan pendapatan. Sampel yang digunakan yaitu 34 negara sedang berkembang di Afrika pada periode 1976 - 2000. Hasil penelitian menunjukkan bahwa desentralisasi fiskal memiliki pengaruh yang signifikan terhadap kemiskinan dan ketimpangan pendapatan. Desentralisasi fiskal meningkatkan kemiskinan, namun mengurangi ketimpangan pendapatan.

Beberapa penulis berpendapat bahwa desentralisasi fiskal mengarah ke sebuah optimalisasi penyediaan pelayanan publik dan upaya mendorong pertumbuhan ekonomi. Selain itu, mereka berpendapat ada bahaya dari desentralisasi fiskal yaitu yang terkait dengan kompetisi pemungutan redistribusi daerah dan pusat. Lessman (2006) berpendapat bahwa daerah miskin kurang bisa bersaing dalam hal mobilisasi dengan negara yang lebih kaya, karena itu, jika tidak 
dibantu maka daerah miskin akan tetap menjadi daerah miskin. Penelitian Lessman ini secara empiris mengkaji dampak desentralisasi fiskal pada kesenjangan daerah menggunakan panel data untuk 17 negara OECD dari tahun 1980-2001. Hasil penelitian menunjukkan bahwa tingkat desentralisasi fiskal yang tinggi menunjukkan kesenjangan antar daerah yang rendah.

Para peneliti memfokuskan penelitian pada faktor penentu pertumbuhan sektor publik dilihat dari dampak peningkatan federalisme fiskal. Brothaler \& Getzner (2010) mengkaji apakah desentralisasi fiskal memberikan kontribusi terhadap pertumbuhan ekonomi di Austria. Sampel penelitian yang digunakan yaitu Propinsi di Austria 1955-2007. Hasil penelitian menunjukkan bahwa jika ada kenaikan PDB maka pengeluaran pemerintah akan meningkat juga. Pengeluaran pemerintah yang menunjukkan kebijakan fiskal aktif yang akan mengurangi tingkat pengangguran. Hasil uji kointegrasi menunjukkan desentralisasi fiskal secara signifikan mendorong pertumbuhan ekonomi daerah jangka pendek dan jangka panjang.

Selain pertumbuhan ekonomi, keberhasilan desentralisasi fiskal juga ditunjukkan dengan meningkatnya partisipasi dari penduduk lokal dalam pembangunan dan aktivitas ekonomi. Vazquez \& Yao (2009) mengembangkan model untuk menganalisa hubungan antara desentralisasi dan kesempatan kerja pada sektor publik. Mereka menemukan bahwa desentralisasi pengeluaran secara secara signifikan mendorong kesempatan kerja dan dengan kata lain akan mengurangi pengangguran..

Faridi, Chaudry \& Ansari (2012) yang meneliti keterkaitan desentralisasi fiskal dan kesempatan kerja di Pakistan menemukan bahwa efek desentralisasi fiskal berbeda tergantung dan pangsa pendapatan dan pengeluaran masing-masing propinsi sehingga secara signifikan mendorong kesempatan kerja.

Bahl \& Wallace (2006) mengkaji dampak desentralisasi fiskal terhadap pemerataan di Rusia. Sampel yang digunakan yaitu 21 region di Rusia tahun 1997 Pemerintah daerah menggunakan instrumen fiskal campuran untuk menyeimbangkan pengeluaran untuk otonomi daerah yang membutuhkan anggaran lebih besar kepada daerah dan membantu menghilangkan kesenjangan daerah. Selain itu, Bahl \& Wallace (2006) juga mengembangkan metode untuk mempelajari tradeoff antara desentralisasi dan pemerataan. Intinya, bahwa tanpa prioritas dan pemahaman terperinci dalam pengaturan kelembagaan dan hubungan antar pemerintah daerah, maka implikasi dari pemerataan dan desentralisasi tidak dapat berjalan secara optimal.

Penelitian lain tentang negara sedang berkembang yaitu Pakistan. Pakistan adalah negaran dengan ekonomi sedang berkembang yang tingkat pertumbuhan ekonominya belum terlalu tinggi. Berbeda dengan penelitian lain tentang Pakistan, penelitian ini berfokus pada desentralisasi fiskal sebagai sumber utama pertumbuhan ekonomi. Desentralisasi fiskal meningkatkan efisiensi yang mengarah pada pertumbuhan ekonomi. Faridi (2011) menggunakan sampel penelitian Propinsi di Pakistan tahun 1972-2009. Temuan dari penelitian ini menunjukkan bahwa kedua indikator desentralisasi fiskal yaitu pengeluaran dan pendapatan otonomi memiliki dampak positif dan signifikan pada pertumbuhan ekonomi. Berdasarkan hasil penelitian ini, 
maka Faridi (2011) menganjurkan pemerintah federal harus mendelegasikan kuasa fiskal pada pemerintah propinsi dan kabupaten untuk meningkatkan pertumbuhan dan kesejahteraan rakyat Pakistan.

Sebagian besar literatur desentralisasi fiskal cenderung menekankan pada kapasitas desentralisasi fiskal yang besar dalam rangka kebijakan dan pelayanan publik. Dengan semakin besar efisiensi pemerintah, maka dapat mendorong pertumbuhan ekonomi. Namun, bukti efisiensi pemerintah masih jarang ditemukan. Pose (2009), dalam tulisannya, ia menggunakan pendekatan data panel untuk mengkaji hubungan antara tingkat desentralisasi fiskal dan tingkat pertumbuhan ekonomi di 16 negara tengah dan Eropa Timur pada periode 1990 -2004. Temuan Spenelitian menunjukkan bahwa hasil di Eropa Timur bertentangan dengan pandangan mayoritas, ada hubungan negatif yang signifikan antara desentralisasi fiskal dan pertumbuhan ekonomi. Namun, ada indikasi dalam jangka panjang hasilnya mungkin berbeda. Transfer pusat ke daerah memiliki hubungan negatif dengan pertumbuhan ekonomi, tingkat pajak yang ditetapkan pada tingkat daerah berevolusi memiliki hubungan negatif dengan tingkat pertumbuhan nasional, namun positif dengan pertumbuhan ekonomi daerah. Hal ini sesuai dengan pandangan yang menyatakan bahwa dengan sumber pendapatan sendiri, sebuah daerah dapat mendorong produksi lokal untuk merespon permintaan lokal.

\section{METODOLOGI}

\subsection{Data}

Penelitian ini menggunakan data sekunder yang bersumber dari BPS, Kementrian Keuangan serta institusi lainnya. Data yang digunakan adalah APBD, PDRB, angka kemiskinan, jumlah penduduk, Indeks Pembanguan Manusia (IPM), Pengeluaran, Tenaga Kerja dan data lain yang relevan dengan penelitian ini. Data yang digunakan adalah data tahun 1990 - 2011 untuk data 26 propinsi di Indonesia.

\subsection{Model Empiris dan Teknik Estimasi}

Metode analisis yang digunakan dalam penelitian ini adalah analisis deskriptif dan metode data panel dengan Generalized Least Square (GLS). Model Data Panel statis (Fixed Effect Model dan Random Effect Model). Pengelolaan data menggunakan program Software STATA .

Berdasarkan penelitian terdahulu spesifikasi model panel yang digunakan dalam penelitian ini mengadopsi pada model yang digunakan Muslianti (2011) dan Sobari (2011) yakni:

$$
\text { Growth }=\beta_{0}+\beta_{1} \text { InYcap }+\beta_{2} \text { In }+\beta_{3} S c h+\beta_{4} D D F
$$


Model di atas diadopsi dari studi Aisyah (2008) dengan judul The Effect of Fiscal Decentralization on Economic Growth. Model yang dikembangkan menggunakan DDF (Derajat Desentralisasi Fiskal).

Ukuran Derajat Desentralisasi Fiskal mengadopsi dari IMF mengenai Fiscal Decentralization Indicators yang mengukur dari sisi pengeluaran. Pengukuran ini sejalan dengan desentralisasi fiskal di Indonesia yang lebih menekankan kepada desentralisasi dari sisi pengeluaran.

Adapun perhitungan DDF tersebut :

$$
\boldsymbol{D D F}_{i t}=\frac{T B \text { Prov }_{i t}}{\text { TB Pusat } t-\operatorname{Trf} \text { Pusat ke Prov it }+ \text { TB Prov it }}
$$

di mana DDF ${ }_{\text {it }}$ adalah derajat desentralisasi fiskal kabupaten/kota i, pada tahun t; TB Prov menunjukkan total belanja kabupaten/kota i, pada tahun t; TB Pusat adalah total belanja pusat pada tahun t; dan Trf Pusat ke Prov ${ }_{\text {it }}$ adalah transfer pusat atau dana perimbangan ke provinsi i, pada tahun t. Sebagai catatan, sebelum desentralisasi fiscal maka angka yang digunakan adalah Subsidi Dearah Otonom.

\section{HASIL DAN ANALISIS}

Penelitian ini mengulas bagaimana variasi yang dihasilkan dari desentralisasi fiskal terhadap pertumbuhan ekonomi. Selain itu, juga akan ditelaah bagaimana kesuksesan suatu daerah pasca desentralisasi fiskal (yang direpresentasikan dengan Derajat Desentralisasi Fiskal) berkorelasi terhadap variabel-variabel pembangunan ekonomi yang telah disebutkan sebelumnya.

Lebih jauh lagi, selain analisis di tingkat nasional, estimasi juga dilakukan dengan menggunakan sub sampel masing-masing wilayah dengan pembagian sebagai berikut:

\begin{tabular}{l|l}
\multicolumn{1}{c}{\begin{tabular}{c} 
Tabel 2. \\
\multicolumn{1}{c|}{ Wembagian Regional Propinsi-Propinsi di Indonesia } \\
Sumatera
\end{tabular}} & \multicolumn{1}{c}{ Propinsi } \\
\hline Jawa dan Bali & DI Aceh, Sumatera Utara, Sumatera Barat, Riau, Jambi, Sumatera Selatan, Bengkulu, Lampung \\
\hline Kalimantan & Kalimantan Barat, Kalimantan Tengah, Kalimantan Selatan, Kalimantan Timur \\
\hline $\begin{array}{l}\text { Sulawesi } \\
\text { Timur }\end{array}$ & $\begin{array}{l}\text { Sulawesi Utara, Sulawesi Tengah, Sulawesi Selatan, Sulawesi Tenggara } \\
\text { Nusa Tenggara Barat, Nusa Tenggara Timur, Maluku, Papua }\end{array}$ \\
\hline
\end{tabular}




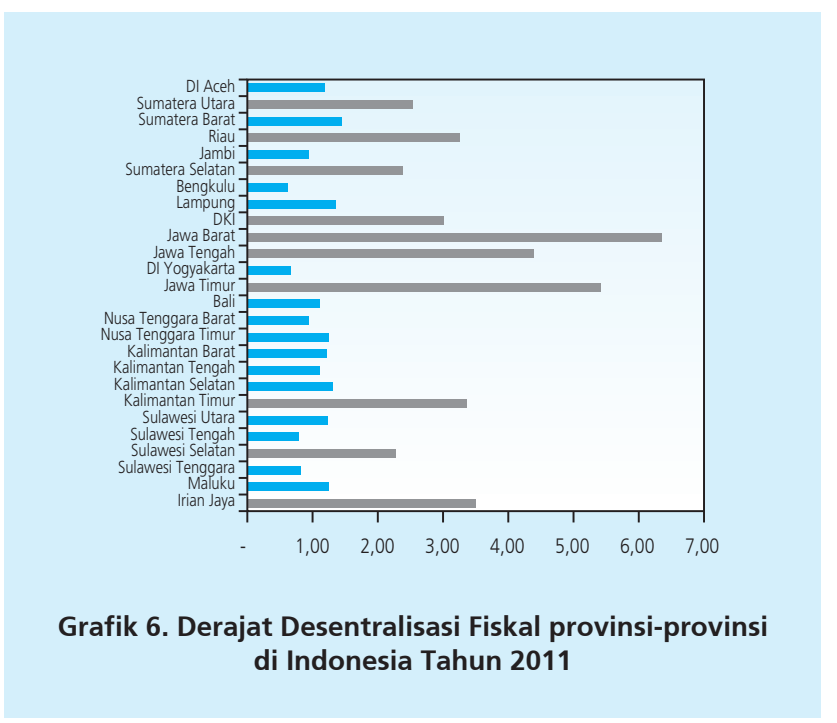

Grafik 6 menampilkan perbandingan Derajat Desentralisasi Fiskal antar propinsi di Indonesia pada tahun 2011, yang dikalkulasi dengan membagi Total Belanja Propinsi terhadap Total Belanja Pusat dikurang dengan Transfer Pusat (Dana Perimbangan) ke Propinsi ditambah dengan Total Belanja Propinsi. Warna merah menunjukkan daerah yang sudah memenuhi tingkat kemandirian yang 'cukup'. Dari 26 propinsi di Indonesia, hanya terdapat 10 propinsi dengan tingkat kemandirian yang sudah tergolong cukup (rule of thumb rasio di atas adalah 2 dan ditunjukan dengan warna merah).

Pendekatan formula desentralisasi fiskal dari sisi pengeluaran ini mengacu pada formula IMF dan sejalan dengan desentralisasi fiskal di Indonesia yang lebih menekankan kepada desentralisasi dari sisi pengeluaran. Gambaran ini menunjukan bahwa sebagian besar propinsi masih belum mandiri dalam pengeluaran daerahnya. Hal ini dapat dijelaskan bahwa terdapat beberapa permasalahan antara lain dalam pengelolaan keuangan daerah itu sendiri, serta program-program yang harus dilakukan daerah yang merupakan alokasi dari pemerintah pusat. Kegiatan pemerintah pusat di daerah seperti pelayanan kepada masyarakat melalui subsidi, dana dekonsentrasi, tugas pembantuan, hibah dll. yang apabila dihitung secara keseluruhan, maka dana yang mengalir ke daerah telah mencapai kisaran 60\% dari belanja negara. Dengan demikian maka tidaklah mengherankan apabila pemerintah daerah dibeberapa propinsi kurang maksimal dalam menggunakan dana transfer fiskalnya.

Tabel 2 menampilkan hasil regresi untuk indikator pertumbuhan PDRB propinsi dengan model regresi yang diadopsi dari studi Aisyah (2008). Penggunaan variabel persentase penduduk yang menamatkan perguruan tinggi pada penelitian Aisyah diganti dengan variabel rata-rata lama usia sekolah. Model apabila diestimasi dalam bentuk fixed effect akan menghasilkan pelanggaran heteroskedastisitas, sehingga dialterasi ke dalam model GLS. Model secara 
keseluruhan terbukti mampu dalam menjelaskan fenomena pertumbuhan ekonomi. Pada Tabel 2 dapat dilihat hasil rangkuman estimasi secara keseluruhan (26 provinsi) dan per wilayah yang dibagi kedalam kelompok tahun yakni tahun 1990 -2011, periode sebelum desentralisasi 1990 -2000 dan periode setelah desentralisasi 2001-2011. Tabel 2 tersebut juga menampilkan ringkasan temuan estimasi untuk semua kawasan. Sekalipun secara umum model efisien pada ketiga interval waktu, terdapat beberapa variasi variabel yang signifikan pada masing-masing kawasan.

PDRB per kapita memiliki hubungan yang lurus dengan tingkat pertumbuhan ekonomi daerahnya dan berpengaruh secara signifikan untuk nasional baik pada periode 1990 -2011 maupun pada periode sebelum desentralisasi, 1990 -2000. Sementara itu makin besar porsi investasi dalam output mestinya memberi efek positif terhadap pertumbuhan ekonomi daerah, namun observasi nasional justru memberi efek yang berlawanan untuk periode sebelum dan sesudah desentralisasi dan periode sebelum desentralisasi yakni peningkatan investasi mempunyai korelasi yang negatif terhadap pertumbuhan ekonomi.

Kemudian daerah yang sudah mencapai performa pendidikan yang mapan memiliki hubungan yang searah dengan pertumbuhan ekonomi. Pengaruh tingkat pendidikan terhadap pertumbuhan ekonomi secara signifikan ditunjukan oleh variabel schooling dengan pertumbuhan PDRB pada periode 1990-2000 namun dengan arah yang berlawanan. Di lain pihak, kemandirian fiskal suatu daerah terbukti memberi hubungan yang signifikan dengan pertumbuhan ekonomi daerah tersebut terutama terbukti setelah periode desentralisasi fiskal (2001-2011) yakni apabila kemandirian fiskal (DDF) meningkat 3\% maka akan mendorong peningkatan pertumbuhan ekonomi sebesar $1 \%$.

\section{Wilayah Sumatera}

Propinsi yang lebih tinggi tingkat pendapatan masyarakatnya terbukti memiliki tingkat pertumbuhan yang lebih tinggi pula, ini terjadi pada periode panjang yakni 1990-2011 dan pada masa setelah desentralisasi. Hubungan terbalik justru terjadi pada periode sebelum desentralisasi. Sementara itu investasi tidak memberikan pengaruh dalam periode sebelum dan setelah desentralisasi, namun memiliki hubungan yang terbalik dan signifikan pada periode panjang 1990-2011.

Tingkat pendidikan yang lebih tinggi terbukti mempunyai hubungan yang berlawanan dengan pertumbuhan ekonomi, tetapi hanya terjadi pada periode setelah desentralisasi. Sedangkan pada periode sebelum desentralisasi variabel ini memberikan efek yang berbanding lurus dengan pertumbuhan ekonomi. Kemudian, pada interval manapun terlihat bahwa daerah yang lebih mandiri secara fiskal tidak memberikan pengaruh pada pertumbuhan ekonomi daerah. 


\begin{tabular}{|c|c|c|c|c|c|c|c|}
\hline \multicolumn{8}{|c|}{$\begin{array}{l}\text { Tabel } 3 . \\
\text { Hasil Estimasi Model Pertumbuhan }\end{array}$} \\
\hline Variabel & & Tahun & & & & Tahun & \\
\hline $\begin{array}{l}\text { Nasional/ } \\
\text { PDRB }\end{array}$ & $1990-2011$ & $1990-2000$ & $2001-2011$ & $\begin{array}{l}\text { Wilayah } \\
\text { Kalimantan }\end{array}$ & $1990-2011$ & $1990-2000$ & 2001-2011 \\
\hline Const & $\begin{array}{r}-15,07695^{*} \\
(0.001)\end{array}$ & $\begin{array}{r}1,19367 \\
(0.765)\end{array}$ & $\begin{array}{r}5,75334^{*} \\
(0.000)\end{array}$ & Const & $\begin{array}{r}3,24071^{*} \\
(0.000)\end{array}$ & $\begin{array}{r}4,16614^{*} \\
(0.000)\end{array}$ & $\begin{array}{r}2,82141^{*} \\
(0.000)\end{array}$ \\
\hline Y cap & $\begin{array}{r}0,05618^{*} \\
(0.000)\end{array}$ & $\begin{array}{r}0,07174^{*} \\
(0.000)\end{array}$ & $\begin{array}{r}0,00693 \\
(0.326)\end{array}$ & Y cap & $\begin{array}{r}-0,01137 \\
(0.212)\end{array}$ & $\begin{array}{r}0,09903^{*} \\
(0.020)\end{array}$ & $\begin{array}{r}0,00231 \\
(0.802)\end{array}$ \\
\hline Inv & $\begin{array}{r}-0,02673^{*} \\
(0.005)\end{array}$ & $\begin{array}{r}-0,04298^{*} \\
(0.009)\end{array}$ & $\begin{array}{r}0,00362 \\
(0.591)\end{array}$ & $\operatorname{lnv}$ & $\begin{array}{r}-0,01939^{*} \\
(0.019)\end{array}$ & $\begin{array}{r}-0,07885^{*} \\
(0.000)\end{array}$ & $\begin{array}{r}0,00102 \\
(0.887)\end{array}$ \\
\hline Sch & $\begin{array}{r}0,00559 \\
(0.389)\end{array}$ & $\begin{array}{r}-0,06171^{*} \\
(0.000)\end{array}$ & $\begin{array}{r}0,00302 \\
(0.641)\end{array}$ & Sch & $\begin{array}{r}0,01194 \\
(0.588)\end{array}$ & $\begin{array}{r}-0,10166^{*} \\
(0.003)\end{array}$ & $\begin{array}{r}-0,06313^{*} \\
(0.000)\end{array}$ \\
\hline DDF & $\begin{array}{r}0,00358 \\
(0.641)\end{array}$ & $\begin{array}{r}-0,00858 \\
(0.461)\end{array}$ & $\begin{array}{r}0,03030^{*} \\
(0.001)\end{array}$ & DDF & $\begin{array}{r}-0,01008 \\
(0.712)\end{array}$ & $\begin{array}{r}-0,03092 \\
(0.239)\end{array}$ & $\begin{array}{r}0,01336^{*} \\
(0.000)\end{array}$ \\
\hline $\begin{array}{l}\text { Wilayah } \\
\text { Sumatera }\end{array}$ & & & & $\begin{array}{l}\text { Wilayah } \\
\text { Sulawesi }\end{array}$ & & & \\
\hline Const & $\begin{array}{r}-5,44965^{\star} \\
(0.033)\end{array}$ & $\begin{array}{r}3,41242^{*} \\
(0.015)\end{array}$ & $\begin{array}{r}-6,58796^{*} \\
(0.001)\end{array}$ & Const & $\begin{array}{r}1,82043^{*} \\
(0.055)\end{array}$ & $\begin{array}{r}1,62069 \\
(0.187)\end{array}$ & $\begin{array}{l}0,16583 \\
0,87100\end{array}$ \\
\hline Y cap & $\begin{array}{r}0,06509^{*} \\
(0.004)\end{array}$ & $\begin{array}{r}-0,03613^{*} \\
(0.047)\end{array}$ & $\begin{array}{r}0,18093^{*} \\
(0.000)\end{array}$ & Y cap & $\begin{array}{r}0,00524 \\
(0.616)\end{array}$ & $\begin{array}{r}0,01504 \\
(0.710)\end{array}$ & $\begin{array}{r}-0,05742 \\
0,21100\end{array}$ \\
\hline Inv & $\begin{array}{r}-0,04895^{*} \\
(0.004)\end{array}$ & $\begin{array}{r}0,03276 \\
(0.164)\end{array}$ & $\begin{array}{r}-0,05393 \\
(0.068)\end{array}$ & Inv & $\begin{array}{r}-0,01590 \\
(0.175)\end{array}$ & $\begin{array}{r}-0,04311^{*} \\
(0.000)\end{array}$ & $\begin{array}{l}0,01994 \\
0,51900\end{array}$ \\
\hline Sch & $\begin{array}{r}-0,01366 \\
(0.191)\end{array}$ & $\begin{array}{r}0,08348^{*} \\
(0.000)\end{array}$ & $\begin{array}{r}-0,05212^{*} \\
(0.007)\end{array}$ & Sch & $\begin{array}{r}0,00581 \\
(0.747)\end{array}$ & $\begin{array}{r}-0,00483 \\
(0.853)\end{array}$ & $\begin{array}{r}0,07515^{*} \\
0,04500\end{array}$ \\
\hline DDF & $\begin{array}{r}0,01038 \\
(0.378)\end{array}$ & $\begin{array}{r}-0,02630 \\
(0.434)\end{array}$ & $\begin{array}{r}-0,02120 \\
(0.499)\end{array}$ & DDF & $\begin{array}{r}0,01275 \\
(0.263)\end{array}$ & $\begin{array}{r}0,01525 \\
(0.569)\end{array}$ & $\begin{array}{r}0,01535 \\
(0,698)\end{array}$ \\
\hline $\begin{array}{l}\text { Wilayah } \\
\text { Jawa \& Bali }\end{array}$ & & & & $\begin{array}{l}\text { Wilayah } \\
\text { Timur }\end{array}$ & & & \\
\hline Const & $\begin{array}{r}-2,53442 \\
(0,219)\end{array}$ & $\begin{array}{r}2,92942 \\
(0,497)\end{array}$ & $\begin{array}{r}0,25570 \\
(0,674)\end{array}$ & Const & $\begin{array}{r}4,58749^{*} \\
(0.000)\end{array}$ & $\begin{array}{r}3,67977^{*} \\
(0,045)\end{array}$ & $\begin{array}{r}0,95037 \\
(0,475)\end{array}$ \\
\hline Y cap & $\begin{array}{r}0,15374^{*} \\
(0.000)\end{array}$ & $\begin{array}{r}0,21046^{*} \\
(0,003)\end{array}$ & $\begin{array}{r}0,00962 \\
(0,32)\end{array}$ & Y cap & $\begin{array}{r}0,03600 \\
(0,449)\end{array}$ & $\begin{array}{r}0,09376^{*} \\
(0,003)\end{array}$ & $\begin{array}{r}-0,01597 \\
(0,411)\end{array}$ \\
\hline Inv & $\begin{array}{r}-0,11163^{*} \\
(0,003)\end{array}$ & $\begin{array}{r}-0,22187 \\
(0,065)\end{array}$ & $\begin{array}{r}0,01753^{*} \\
(0,017)\end{array}$ & Inv & $\begin{array}{r}-0,00745 \\
(0,678)\end{array}$ & $\begin{array}{r}-0,07249^{*} \\
(0,01)\end{array}$ & $\begin{array}{r}0,01747 \\
(0,419)\end{array}$ \\
\hline Sch & $\begin{array}{r}-0,08042^{*} \\
(0,031)\end{array}$ & $\begin{array}{r}-0,21025 \\
(0,089)\end{array}$ & $\begin{array}{r}0,01365 \\
(0,147)\end{array}$ & Sch & $\begin{array}{r}-0,05907^{*} \\
(0,013)\end{array}$ & $\begin{array}{r}-0,08400 \\
(-0,064)\end{array}$ & $\begin{array}{r}0,00242 \\
(0,909)\end{array}$ \\
\hline DDF & $\begin{array}{r}0,05846^{*} \\
(0,003)\end{array}$ & $\begin{array}{r}0,04955 \\
(0,399)\end{array}$ & $\begin{array}{r}0,25570 \\
(0,674)\end{array}$ & DDF & $\begin{array}{r}-0,03376 \\
(0,247)\end{array}$ & $\begin{array}{r}0,02407 \\
(0,385)\end{array}$ & $\begin{array}{r}-0,00230 \\
(0,929)\end{array}$ \\
\hline
\end{tabular}




\section{Wilayah Jawa dan Bali}

Pada kawasan ini, model terbukti signifikan pada periode panjang yakni sebelum dan sesudah desentralisasi untuk semua variabel. Daerah yang lebih makmur di kawasan ini mempunyai pengaruh terhadap pertumbuhan, terutama untuk periode 1990-2011 dan periode 1990 -2000. Di lain pihak, tingginya investasi pada suatu propinsi mempunyai pengaruh positif terhadap pertumbuhan ekonomi terutama terjadi pada periode setelah desentralisasi fiskal. Namun pada periode panjang (1990-2011) pengaruh investasi justru berlawanan arah dengan pertumbuhan ekonomi. Demikian pula dengan pengaruh pendidikan yang makin tinggi mempunyai hubungan terbalik dengan pertumbuhan ekonomi dikawasan ini pada periode 1990-2011. Kemandirian fiskal terbukti memberikan dampak yang signifikan dan positif pada pertumbuhan ekonomi kawasan ini yang terjadi pada periode 1990-2011.

\section{Wilayah Kalimantan}

Temuan untuk kawasan Kalimantan, pendapatan perkapita yang tinggi memberikan pengaruh signifikan pada pertumbuhan ekonomi kawasan terutama pada periode sebelum desentralisasi. Daerah yang lebih makmur di Kalimantan tumbuh lebih cepat, terlihat pada masa sebelum desentralisasi. Sementara itu investasi memilki hubungan yang terbalik pada periode panjang 1990 -2011 dan sebelum desentralisasi, dengan pengaruh signifikan pada level signifkansi 95\%. Tingginya tingkat pendidikan sebelum dan sesudah otonomi daerah juga membawa hubungan terbalik terhadap pertumbuhan ekonomi dengan efek yang signifikan. Selanjutnya terdapat hubungan yang signifikan antara kemandirian fiskal kawasan ini dengan tingkat pertumbuhan propinsi di Kalimantan terutama setelah periode desentralisasi fiskal.

\section{Wilayah Sulawesi}

Untuk kawasan Sulawesi, variabel pendapatan perkapita tidak signifikan berpengaruh terhadap pertumbuhan ekonomi untuk kawasan ini pada semua periode observasi. Sedangkan investasi berpengaruh signifikan terhadap pertumbuhan ekonomi kawasan ini namun dalam hubungan yang terbalik. Variabel pendidikan yang tinggi berpengaruh positif dan signifikan terhadap pertumbuhan ekonomi kawasan ini.

\section{Wilayah Timur}

Untuk wilayah Timur, pendapatan penduduk yang tinggi memilki pengaruh yang positif dan signifikan terhadap pertumbuah ekonomi kawasan ini. Terutama model ini signifkan pada masa sebelum desentralisasi. Demikian juga investasi yang berpengaruh terhadap pertumbuhan namun dengan hubungan yang terbalik. Pada periode panjang, ditemukan juga bahwa daerah 
dengan tingkat pendidikan yang lebih tinggi mempunyai pengaruh yang berlawanan dengan pertumbuhan ekonomi pada periode 1990-2011.

Variabel PDRB riil per kapita dihipotesiskan untuk berbanding lurus dengan pertumbuhan PDRB suatu propinsi. Sebagaimana dikemukan oleh Wagner bahwa dalam suatu perekonomian apabila pendapatan perkapita meningkat, secara relatif pengeluaran pemerintah akan meningkat dan pada akhirnya akan meningkatkan pertumbuhan ekonomi. Estimasi di tingkat nasional, Sumatera (juga setelah periode desentralisasi), kawasan Jawa \& Bali, Kalimantan dan kawasan Timur, menunjukan signifikansi positif pengaruh pendapatan per kapita terhadap pertumbuhan ekonomi. Hanya di wilayah Sulawesi, PDRB per kapita tidak memberikan pengaruh terhadap pertumbuhan ekonomi.

Sesuai dengan teori pertumbuhan Solow, pertumbuhan ekonomi dapat dimotori oleh tingkat investasi yang tinggi pada suatu daerah. Hipotesis ini umumnya dapat dibuktikan pada masa sebelum desentralisasi namun dengan hubungan yang terbalik baik nasional dan kawasan. Hanya di Jawa dan Bali pada interval pengamatan 2000-2011 hipotesis ini terbukti secara positif dan signifikan. Temuan-temuan ini disebabkan karena pada observasi di periode manapun, ekonomi setiap propinsi di Indonesia cenderung untuk tumbuh stabil di kisaran 5\% setiap tahunnya. Hal ini pun juga menjelaskan mengapa banyak estimasi yang tidak signifikan pada model ini.

Kemandirian fiskal yang direpresentasikan oleh derajat desentralisasi fiskal (DDF) dihipotesiskan dapat memacu pergerakan ekonomi suatu daerah. Hipotesis ini terbukti pada observasi level nasional, dan wilayah Kalimantan untuk periode setelah desentralisasi fiskal. Sementara itu untuk kawasan Jawa \& Bali memiliki efek positif dan signifikan pada periode sebelum desentralisasi. Kebijakan pengelolaan keuangan daerah secara mandiri memberikan hasil yang positif terhadap pertumbuhan ekonomi secara nasional. Hasil empiris ini sejalan dengan penelitian yang dilakukan oleh Oates (1993), Gramlich (1993) dan lain-lain.

Variabel DDF untuk wilayah-wilayah lainnya yang tidak berpengaruh terhadap pertumbuhan ekonomi daerah ditentukan pula oleh faktor-faktor lain. Misalnya dalam DDF terkandung unsur dana perimbangan setelah dilakukan desentralisasi fiskal (sebelum itu pemerintah pusat menyalurkan dana subsidi daerah otonom (SDO)). Sebagaimana telah disampaikan pada bab 1 bahwa dana transfer fiskal ini terus mengalami peningkatan dan cenderung mengalami ketimpangan setiap tahunnya (Fatimah, 2007). Ketimpangan transfer fiskal ini terkait erat dengan formula pembagian dana transfer yang dipengaruhi oleh SDA yang tersedia di daerah. Daerah yang kaya SDA akan diuntungkan. Selain itu Total Belanja Daerah sangat ditentukan oleh pengelolaan keuangan daerah dimana proporsi terbesar belanja daerah adalah belanja pegawai (44\% dari APBD) sementara itu proporsi belanja modal relatif lebih kecil (22\%) sehingga pengaruhnya terhadap pertumbuhan ekonomi relatif tidak besar. Faktor lain yang mempengaruhi belanja/pengeluaran daerah adalah besarnya dana transfer fiskal 
yang belum tergunakan oleh daerah yang disimpan di bank terdiri dari simpanan berjangka, giro dan tabungan.

\section{KESIMPULAN}

Paper ini menganalisa pengaruh kebijakan desentralisasi fiskal terhadap tingkat petumbuhan ekonomi daerah di Indonesia. Dengan menggunakan data 26 propinsi yang diestimasi dengan metode panel, maka paper ini menghasilkan beberapa temuan di bawah ini.

Pertama, otonomi keuangan daerah yang direpresentasikan dalam bentuk Derajat Desentralisasi Fiskal (DDF), untuk nasional berpengaruh positif dan signifikan terhadap pertumbuhan ekonomi pada masa setelah desentralisasi fiskal. Ini berarti kemandirian dalam pengeluaran fiskal akan mendorong pertumbuhan ekonomi propinsi yang bersangkutan. Kondisi ini sesuai dengan Hukum Wagner yang menyatakan bahwa dalam suatu perekonomian apabila pendapatan per kapita meningkat, secara relatif pengeluaran pemerintah juga meningkat yang pada akhirnya akan meningkatkan pertumbuhan ekonomi. Pada sub sampel untuk masingmasing wilayah, pengaruh positif dari pendapatan per kapita terhadap pertumbuhan hanya terbukti pada wilayah Jawa dan Bali dan hanya berlaku dalam periode observasi panjang (1990-2011).

Temuan kedua dari paper ini adalah dengan menggunakan data nasional variabel pendapatan per kapita signifikan berpengaruh secara positif pada periode 1990-2011 dan periode sebelum desentralisasi fiskal. Pada tingkat regional, pengaruh positif dijumpai untuk wilayah Sumatera pada periode 1990-2011 dan periode setelah desentralisasi fiskal 20012011. Untuk wilayah Jawa \& Bali, pengaruh positif dari pendapatan perkapita berlaku untuk periode sebelum desentralisasi fiskal dan periode 1990-2011. Untuk Kalimantan dan Wilayah Timur pengaruh pendapatan perkapita signifikan terhadap pertumbuhan ekonomi hanya pada periode sebelum desentralisasi fiskal.

Temuan ketiga, pengaruh tingkat investasi terhadap pertumbuhan ekonomi justru menunjukkan hubungan yang terbalik. Pengaruh positif investasi terhadap pertumbuhan ekonomi hanya dijumpai untuk wilayah Jawa dan Bali pada interval 2000-2011.

Temuan di atas menggiring pada kesimpulan yakni bahwa pengaruh desentralisasi fiskal terhadap pertumbuhan ekonomi tidak konskusif untuk kasus desentralisasi di Indonesia. Tidak sesuainya bukti empiris dengan teori ini dapat dipengaruhi oleh formula transfer fiskal yang diberikan pemerintah pusat kepada pemerintah daerah. Selain itu Total Belanja Daerah sangat ditentukan oleh pengelolaan keuangan daerah dimana proporsi terbesar belanja daerah adalah belanja pegawai (44\% dari APBD) sementara itu proporsi belanja modal relatif lebih kecil (22\%) sehingga pengaruhnya terhadap pertumbuhan ekonomi relatif tidak besar. 
Dengan memperhatikan pengelolaan belanja daerah dimana belanja pemerintah daerah lebih besar porsinya untuk belanja rutin dibandingkan dengan belanja modal sehingga efek dari belanja atau pengeluaran pemerintah daerah belum dapat mengatasi permasalahanpermasalahan dimaksud. Untuk itu pemerintah pusat perlu membuatkan mekanisme yang mendorong pemerintah daerah untuk memaksimalkan belanja modalnya.

Perlu digarisbawahi bahwa penelitian yang diangkat dalam paper ini memiliki beberapa keterbatasan, antara lain pertama kemungkinan penggunaan proksi yang lebih baik dari indeks kemandirian fiskal. Kedua, estimasi dilakukan dengan membuat periodesasi. Sebagai alternatif, paper ini dapat dikembangkan dengan pendekatan switching regime model. 


\section{DAFTAR PUSTAKA}

Adi PH. (2006). Dampak Desentralisasi Fiskal Terhadap Pertumbuhan Ekonomi. Jurnal Kritis. Universitas Kristen Satya Wacana, Salatiga.

Ahmad, Ehtisham and Mansoor, Ali. (2000). Indonesia:Managing Decentralization, Conference on Fiscal Decentralization, Fiscal Affairs Department.

Ananta, Aris, Soekarni, Muljana, and Arifin, Sjamsul et all. (2011). The Indonesian Economy: Entering A New Era, Bank Indonesia and ISEAS.

Boetti, Lorenzo; Piacenza, Massimiliano; Turati, Gilberto. (2009). Fiscal Decentralization and Spending Efficiency of Local Governments; An empirical Investigation on a Sample of 4 Italian Municipalities, University of Torino, Italy.

Bonet, Jaime. (2006). Fiscal Desentralization and Regional Income Disparities:Evidence from the Colombia Experience.

Braun, Joachim von and Grote, Ulrike. (2000) Does Decentralization Serve the Poor?. Center for Development Research, University of Bon, Bon.

Davoodi, Hamid and Zou, Heng-fu. (1997). Fiscal Decentralization and Economic Growth: A Cross -Country Study, Policy Research Department. World Bank. Washington DC, Wuhan University, Wuhan.

Ebel, Robert D., and Yilmaz Serdar. (2003). On The Measurement and Impact of Fiscal Decentralization. Policy Research, World bank, Washington D.C.

Fatimah, Halida. (2007). Dampak Kebijakan Desentralisasi Fiskal Terhadap Tingkat Ketimpangan Pendapatan Antar Propinsi di Indonesia, Institut Pertanian Bogor, Indonesia.

Jin, Jing and Zou, Heng-fu, Fiscal Decentralization and Economic Growth in China, Development Research Group, World Bank, Washington D.C.

Mankiw. (2006). Macroeconomics. 6th Edition, New York: Worth Publisher.

Muslianti. (2011).Dampak Kebijakan Fiskal Daerah terhadap Kemiskinan di Indonesia pada Masa Desentralisasi Fiskal. Tesis. Bogor: IPB

Sobari, Achmad. (2011). Dampak Desentralisasi Fiskal terhadap Pembangunan Sosial Ekonomi Daerah di Indonesia. Tesis. Bogor: IPB.

Subiyantoro, Heru; Riphat, Singgih. (2004). Kebijakan Fiskal: Pemikiran, Konsep dan Implementasi, Kompas, Jakarta.

Suwandi and Waroka, Ari. (2013). Fiscal decentralization and Special Local Autonomy: Evidence from an Emerging Market. Journal of Southeast Asian Research. 
Swastyardi, Drisnaf. (2008). Regional Inequality in Indonesia: Is the general allocation (DAU) likely to have an impact? Graduate School of Development Studies, The Hague, Netherlands.

Vazquaz, J M, McNab, Robert M. (1997). Fiscal Decentralization, Economic Growth and Democratic Governance, Economics Departement Policy Research Center Georgia State University, Washington D.C.

Yamoah, Afia Boadiwaa. (2007). The Effect of Fiscal Decentralization on Economic Growth in U.S. Countries, Graduate School of The Ohio State University, U.S 
206 Buletin Ekonomi Moneter dan Perbankan, Volume 18, Nomor 2, Oktober 2015

Halaman ini sengaja dikosongkan 